\title{
Research \\ Expert and Generalist Local Knowledge about Land-cover Change on South Africa's Wild Coast: Can Local Ecological Knowledge Add Value to Science?
}

\author{
Nigel Chalmers ${ }^{1}$ and $\underline{\text { Christo Fabricius }}^{1}$
}

\begin{abstract}
Local ecological knowledge (LEK) can shed light on ecosystem change, especially in underresearched areas such as South Africa's Wild Coast. However, for ecosystem planning purposes, it is necessary to assess the accuracy and validity of LEK, and determine where such knowledge is situated in a community, and how evenly it is spread. Furthermore, it is relevant to ask: does LEK add value to science, and how do science and local knowledge complement one another? We assessed change in woodland and forest cover in the Nqabara Administrative Area on South Africa's Wild Coast between 1974 and 2001. The inhabitants of Nqabara are "traditional" Xhosa-speaking people who are highly dependent on natural resources for their livelihoods. More recently, however, infrastructural development has influenced traditional lifestyles at Nqabara, although poverty remains high and formal education levels low. We assessed LEK about changes in woodland and forest cover over the past 30 years by interviewing 11 local "experts," who were recognized as such by the Nqabara community, and 40 senior members of randomly selected households in each village. We also analyzed land-cover change, using orthorectified aerial photos taken in 1974 and 2001. Forest and woodland cover had increased by $49 \%$ between 1974 and 2001. The 11 "experts" had a nuanced understanding of these changes and their causes. Their understanding was not only remarkably consistent with that of scientists, but it added considerable value to scientific understanding of the ultimate causes of land-cover change in the area. The experts listed combinations of several causal factors, operating at different spatial and temporal scales. The 40 randomly selected respondents also knew that forest and woodland cover had increased, but their understanding of the causes, and the role of fire in particular, was somewhat simplistic. They could identify only three causal factors and generally listed single factors rather than the combinations of factors listed by the experts. In some instances, their understanding even appeared to be seriously flawed. In contemporary Xhosa society, ecological knowledge is unevenly spread and held by individuals rather than by groups. Therefore, it is important to work with experts rather than randomly selected individuals in ecological studies that incorporate local knowledge. Expert local knowledge adds value to science by providing detailed insights into the ultimate causes of change, and by contributing a rare historical perspective. Scientists add value to local knowledge through their ability to study and predict obscure processes such as the impact of atmospheric change on vegetation. Scientists must, however, acknowledge that positivist studies that compare local knowledge to science are fraught with ethical and methodological challenges. Certain aspects of local knowledge, particularly in terms of fire, are sacred and do not have the same origins as Western science. Local knowledge and science can complement one another, but we advise against integrating them in a way that co-opts local knowledge for scientific purposes.
\end{abstract}

Key Words: cultivation; fire; GIS; land-cover change; landscape ecology; local ecological knowledge; politics; scientific knowledge; vegetation 


\section{INTRODUCTION}

Local ecological knowledge (LEK) has recently received increasing academic and policy attention in biodiversity conservation, ecosystem assessments, and ecosystem management (Heyd 1995, Huntingdon 2000, Gadgil et al. 2003, Alexander et al. 2004, Fabricius et al. 2006). It is particularly valuable in cases where people's livelihoods are closely linked to ecosystem services, particularly in remote rural areas, such as South Africa's Wild Coast, where extensive scientific studies have not been conducted (Reyers and Ginsburg 2005). In such areas, formal scientific studies can be time consuming and expensive, and often require capacity that does not exist (Moller et al. 2004). However, with the use of LEK it is possible to gain insights into ecosystem processes and services, and to use these to improve ecosystem management (Huntingdon 2000). Some scholars have, however, been sceptical about the scientific validity of LEK and its usefulness beyond just the local level, whereas others (e.g., Mauro and Hardison 2000, Hardison 2005) have been concerned about the ethics of exploiting LEK for academic or policy purposes.

Local ecological knowledge offers advantages because it takes a fine-grained, context-specific perspective (Berkes and Folke 2002), which adds value to coarse-scale conservation plans (e.g., Reyers and Ginsburg 2005) or assessments (e.g., Scholes and Biggs 2004). Local knowledge, based on peoples' direct interactions with their environment, is accumulated on a trial-and-error basis through learning from feedback and interaction (Berkes et al. 2003). Such knowledge includes cultural, social, and political knowledge held by groups rather than by individuals (Oudwater and Martin 2003). Institutions, defined as "set(s) of formal and informal rules and norms that shape the interactions of humans with others and nature," that "store," add value to, and share this knowledge within a community are therefore critical (Agrawal and Gibson 1999). Institutions are thus important drivers of landscape pattern (Bebbington and Perreault 1999) because of their direct and indirect influence on ecosystem management practices (Agrawal and Gibson 1999).

Local ecological knowledge is of course not infallible and does have certain limitations. Its finegrained perspective, although adding value to coarse-grained studies, can also be a disadvantage as LEK is often only locally relevant (Gadgil et al. 2003). Therefore, local inhabitants often have a weaker understanding of processes taking place at coarser spatial and temporal scales that are not obvious to them. Faster variables may be easier to identify and observe than slower variables. Local inhabitants are, therefore, able to adapt to them and adjust their knowledge accordingly. However, people often have a limited capacity to integrate slower variables into their understanding of ecosystems as such variables are more difficult to track (Berkes and Jolly 2001).

Local ecological knowledge contrasts with formal, scientific knowledge, which is the conventional source of information for formalized ecosystem management. Scientific knowledge is passed through a strict and agreed upon set of universally accepted rules, which qualifies it for a particular use (Fabricius et al. 2006). It is precise and easily measured in an objective and repeatable manner (Moller et al. 2004). Many scientists are thus sceptical of the validity of informal knowledge in general, because of its perceived subjectivity and lack of rigor (Nadasny 1999, Gadgil et al. 2003). Many ecosystem managers without formal scientific training, on the other hand, are sceptical of science because often they do not understand it, or because it has on some occasions been used politically to mask realities or manipulate the truth (Nadasny 1999, Fabricius et al. 2006).

It is necessary to bring local and scientific knowledge together to improve everyone's understanding of ecosystem services and processes, and to promote mutual respect between the holders of such knowledge (Nadasny 1999). Combining LEK with science is, however, fraught with ethical, methodological, and conceptual difficulties, and merging them does not address the problem. Scholars such as Nadasny (1999), Gadgil et al. (2003) and Cundill et al. (2005) believe that, rather than integrating different forms of knowledge, the gap between them should be bridged so that they can complement and benefit each other.

Knowledge is furthermore unevenly spread within any group, and local communities are no exception. Not everyone has a holistic understanding of the environment, and in rural communities, different groups and individuals use landscapes for different purposes (Kaschula et al. 2005). This leads to the development of local experts, i.e., individuals with above-average knowledge of ecosystems. If 
knowledge about specific resources or processes is required then it is important to select and work with such local experts rather than with arbitrarily selected individuals (Donovan and Puri 2004).

Most studies concerning LEK have focused primarily on species, their distribution, techniques to harvest them, and their medicinal qualities (e.g., Trosper 2002, Lobe and Berkes 2004, Moller et al. 2004, Wang 2004, Kaschula et al. 2005). Few LEK studies have focused on the "processes" that drive change in ecosystems. An understanding of the proximate and ultimate drivers and feedbacks defining change in ecosystem goods and services is, however, of key importance for ecosystem management (Millennium Assessment (MA) 2003). Therefore, this paper focuses on the knowledge of driving processes rather than on that of species.

In this study, we documented LEK about changes in ecosystem structure and landscape pattern on South Africa's Wild Coast. We compared LEK about the extent and causes of change in forest and woodland land cover with scientists' assessments and published understanding of the same processes. A better understanding of land-cover change is particularly relevant on the Wild Coast, as land transformation is believed to be a substantial threat to the area. According to a recent conservation planning exercise (Reyers and Ginsburg 2005), 34\% of the Wild Coast, and 36\% of the Transkei Coastal Belt have been transformed. This has contributed to the setting of quite ambitious conservation targets for these areas (Reyers and Ginsburg 2005). That study was, however, necessarily conducted at a coarse scale without any fine-grained analysis (B. Reyers, pers. comm).

In our study area, anthropogenic disturbance is a key determinant of landscape pattern and land-cover change. Human-induced fire maintains grassland, and its absence drives the transition from grassland to woodland to forest (Kepe and Scoones 1999). Cultivation and clearing also play a role in changing land cover (Andrew and Fox 2004), as do human movement (Fay 2003) and harvesting patterns (Leach and Fairhead 2000).

The objective of our research was to gain an understanding of the strengths and weakness of LEK in explaining ecosystem processes, focusing on human disturbance. We first interviewed a small resident group of local resource users who members of the local Participatory Forest Management
(PFM) committee, regarded as experts about change in forest and woodland cover over the past 30 years. We then gathered data on actual landscape change, using aerial photos. Finally, we conducted interviews with 40 randomly selected residents in the study area about the causes of landscape change.

Our specific key questions were:

- How, according to local experts and generalists, have the shapes and sizes of forest and woodland patches changed over the past 30 years?

- How does this understanding compare to actual land-cover change between 1974 and 2001 ?

- What, according to local experts and generalists, caused these changes?

- How does expert local knowledge compare to generalist local knowledge?

\section{STUDY AREA}

The Nqabara Administrative Area (AA) is located in the Willowvale district in Mbhashe municipality on South Africa's Wild Coast, at 28.503587S, 32.267611 E. The area is bordered by the Nqabara River to the east and the Nqabarana River to the west. This particular area was chosen for the study because of the juxtaposition of forest and grassland, the prevalence of LEK resulting from people's strong dependence on and proximity to natural resources (Mafa Environment and Development cc 2003), and the existence of a functioning local organization (the PFM committee) to use as an entry point.

\section{Biotic Features}

The area falls within a floristic region known as the Tongaland-Pondoland Regional Mosaic (Palmer et al. 2000). The vegetation can best be described as a grassland-woodland-forest mosaic, with a clear distinction between the boundaries of forests, woodland, and grassland because of the effects of fire and clearing for cultivation (Fig. 1). The grassland generally occurs on the high ridges 
whereas the forest patches occur on the moist deeper soils in the protected valleys, with the woodland in a transition zone between the forest and the grassland (Mafa Environment and Development cc 2003). Fire, grazing, soils, and micro-climate contribute to the mosaic landscape (Palmer et al. 2000).

Nqabara is located in a climatic transition zone between the temperate south coast and the subtropical north coast of South Africa. The temperature is moderate with an average winter maximum of $21.5^{\circ} \mathrm{Celsius}$ and $24^{\circ} \mathrm{C}$ in the summer (Mafa Environment and Development cc 2003). The general climatic pattern is one of high temperatures and humidity broken by cooler spells associated with the passage of cold fronts in summer, whereas the winter months are cool and dry and generally frost free. The average rainfall is $1069 \mathrm{~mm}$ yearly measured over 16 years (Palmer et al. 2000). This relatively high rainfall encourages grass growth, which makes dry biomass available for burning during the drier winter months. The high, consistent rainfall also enables the rapid growth of tree saplings, provided they are not destroyed by fire or grazing.

\section{Socioeconomic Features}

The former Transkei was an area set up by the former Government of South Africa under the Bantu SelfGovernment Act of 1959 as a Homeland for the Xhosa Nation (Carter 1959), and is currently part of the Eastern Cape Province. The area is characterized by high unemployment, high levels of poverty, and low education levels. According to a 2001 government census, $70 \%$ of the households of the Nqabara AA earned less than R 500 (\$83 U. $\mathrm{S}$. in 2006) each month. The ratio of young people (under 40) to older people is decreasing (Statistics S.A. 2001), possibly because of out-migration, although HIV/AIDS may also play a role.

Because of low formal rates of employment, most residents rely on welfare grants, cultivation of crops, and especially, natural resources, which are estimated (for the entire Wild Coast) to be worth $\mathrm{R}$ 300-400 (\$50-65 U.S.) per hectare yearly for grassland, and R 2 000-R 12000 (\$333-2 000 U. S.) per hectare yearly for forests (Le Roux and Nahman 2005).

\section{Local Ecological Knowledge}

The Nqabara AA is rich in LEK, although this knowledge is not evenly spread. As with any knowledge system, there are experts, generalists, and uninformed individuals. The local experts have, for example, developed their own sophisticated indigenous forest management plan with the help of facilitators, and established a medicinal plant nursery (Mafa Environment and Development cc 2005). They have proven knowledge of medicinal plant properties and cultivation (Keirungi and Fabricius 2005). The community has elected a PFM committee, with representatives from each village, to deal with governance and institutional issues. They did, however, request the participation of formally trained scientists in the development of their management plan and in the establishment of the medicinal plant garden (Mafa Environment and Development cc 2005). This indicates that they acknowledge the power of LEK when used in conjunction with scientific knowledge.

\section{METHODS}

Data collection consisted of four stages: 1) Semistructured interviews and transect walks with a sample of 11 recognized local experts who had indepth knowledge of ecosystems because their livelihoods were closely linked to natural resources: they spent much of their time in the wild, tending to livestock, and collecting building materials, honey, medicinal plants, and other wild resources. They were identified as experts by the local PFM committee, and were senior members of the community. The purpose of these interviews was to obtain expert information on LEK about change in forest and woodland cover. 2) Semi-structured interviews were conducted with randomly selected households to probe general local understanding of land-cover change and its causes. 3) Aerial photos from 1974 and 2001 were analyzed to assess actual land-cover change in forests and woodlands. 4) A desk-top study of scientific literature was conducted to obtain scientific knowledge on the causes of landscape change, particularly the effect of fire on landscapes, in southern African woodlands and forests.

The questionnaires were designed with a mix of open- and close-ended questions in order to get the relevant information from the respondents, without the use of leading or prompting questions. There 
Fig. 1. A typical patchwork landscape along the Nqabara river.

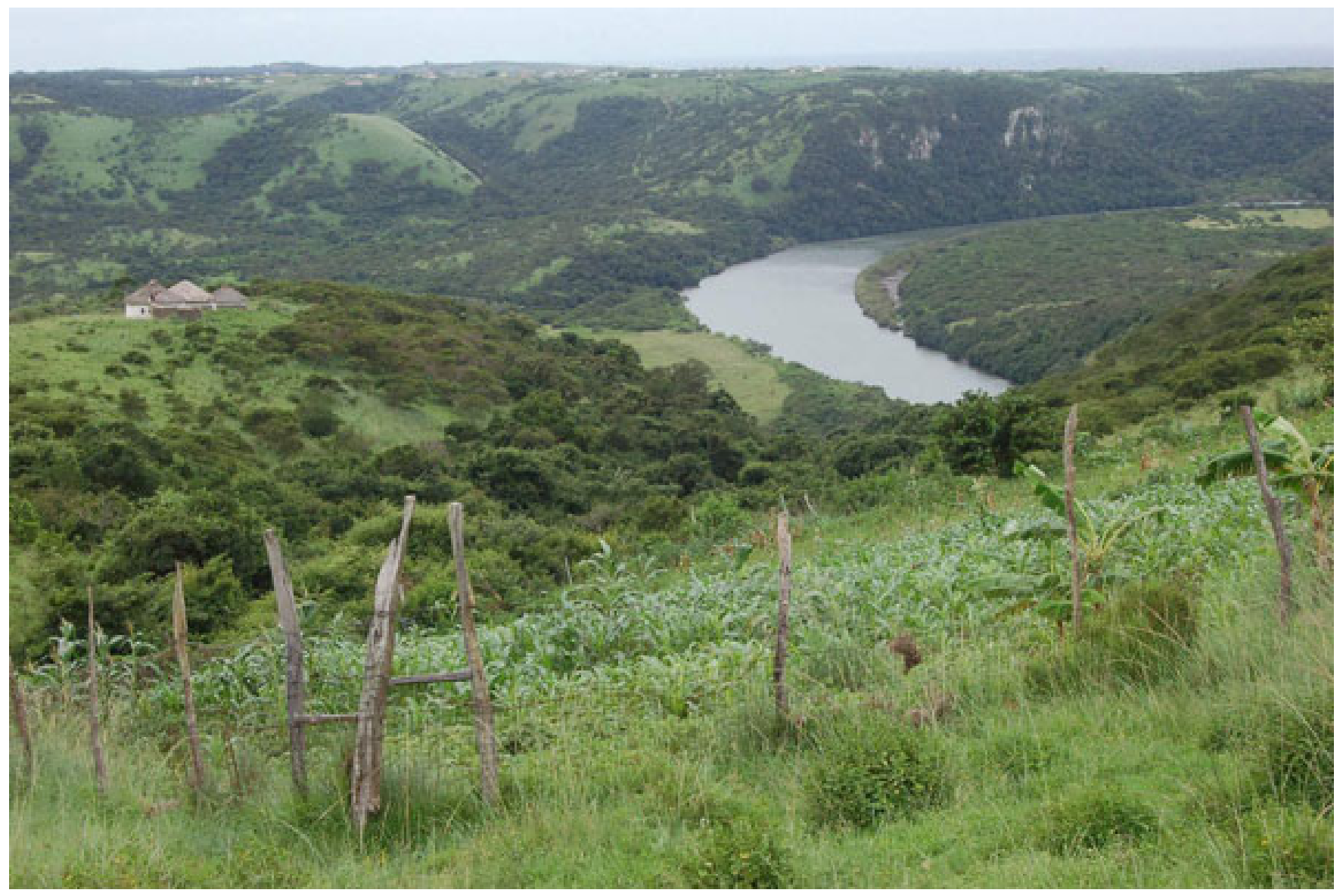

were three drafts of the questionnaire used by the researchers to develop the ideal mix of questions. A month before the field work began, to ensure the meaning was lost in translation, they were piloted, with the help of the translator in Nqabara AA, with people who would not take part in the actual study.

1. Interviews with local experts-Semistructured interviews and transect walks were conducted with the 11 forest experts. Interviews with local experts were conducted during transect walks (Martin 2004) through forests. Discussions took place in isiXhosa and were translated into English with the help of an interpreter. While on the walks, questions were asked and discussions conducted about the changes in forest and woodland composition and cover over the past 30 years, and the causes of such changes.

2. Interviews with randomly selected residents -Forty households were randomly selected. With the help of a trained translator, semistructured interviews (Martin 2004) were administered with the most senior available member of each household. The Nqabara AA is made up of a number of small villages consisting of 15 to 25 homesteads. Each village has sole access to one or more indigenous forest patches for natural resources, within walking distance of homesteads. Villagers had specific knowledge of nearby forest patches, compared with more general knowledge of more distant patches. Interviewees were asked to reflect on all the 
Nqabara forests, but invariably used the ones they were most familiar with as benchmarks. When interviewing the generalist respondents, a household was selected at random and the oldest available member of the household was asked to take part in the interview. Most interviewees $(75 \%)$ were older than 45 , and only one interviewee was younger than 35 . All the interviewees had lived in Nqabara AA their entire lives. The ratio of men to women was 65 to 35 , because most households were headed by men who identified themselves as the most senior household members. The aim of these interviews was to gain information regarding the respondents' understanding of their natural surroundings, with a focus on the effect of human activities on forest and woodland cover.

Statistical analysis of interviews-The data obtained from the semi-structured questionnaires was qualitative and, therefore, the Chisquared test (Rosner 2000) for the significance of relationships between categorical data was used.

3. Spatial analysis - Two sets of orthorectified aerial photographs, one from 1974 and another from 2001, were acquired from the South Africa Department of Land Affairs (2004). Orthorectified images were essential because the topographical variations of Earth's surface and the tilt of the aerial sensor affect the distance with which features on the image are displayed. Displacement can be hundreds of meters (Satellite Image Corporation 2006), and therefore, it is essential to remove distortions. Vector data layers were then created from these images in the form of polygons, representing the outlines of forest and woodlands in 1974 and 2001, respectively. Having digitized the forests and woodlands, it was possible to calculate an area for each patch, enabling us to assess changes in patch sizes between 1974 and 2001. Spatial analysis was conducted using the ArcView 3.2 GIS software program (ESRI 2001, Korte 2001).

4. Desktop study-A desktop study was conducted to gain insight into formal scientific beliefs and understanding concerning the role of fire on landscape dynamics in forests and woodlands. Relevant information was extracted from the literature, in the form of direct quotes or paraphrases, and then compared with direct excerpts from the semistructured interviews with the Nqabara AA residents on LEK.

\section{RESULTS}

\section{Land-cover Change from 1974-2001}

The land cover of the forest and woodland patches increased from 1096 ha in 1974 to 1664 ha in 2001, a $49 \%$ increase overall. The largest recorded increase in forest and woodland cover was $133 \%$ whereas the smallest increase was 2\% (Table 1). The mean increase in the size of forests and woodlands was 37.6 ha \pm 12.04 (SE), which was statistically significant $(t=3.21$ d.f. $=13 ; p<0.01)$. This substantial increase in the size of forests can be seen in the maps of forest and woodland patches in 1974 and 2001 (Fig. 2), and is contrary to conventional wisdom about trends in land cover along the Wild Coast.

\section{Expert Local Knowledge about Land-cover Change}

The 11 local experts demonstrated a highly nuanced understanding of the processes affecting changes in forest size and interiors in the study area. All of them knew that forest and woodland cover had increased since 1974, and they could also indicate which forests had increased the most. The local experts identified six factors that affected forest size and density (Table 2). These were:

1. Increased occurence of exotic trees and shrubs that people do not harvest, as they are seen as inferior in quality to indigenous species.

2. Emigration by people leaving the area, and relocation of homesteads within the area itself.

3. Reduced frequency of fire, which encourages forest expansion around the edges because saplings, especially Acacia karroo (known locally as Umnga), are able to take hold. 
Table 1. Changes in forest and woodland cover in 14 forest patches between 1974 and 2001, as measured from orthorectified aerial photos. All forest patches are indigenous scarp forest (Reyers and Ginsburg 2005), and none have formal protection. The community has, however, submitted proposals and management plans to government for a Nqabara Community Conservancy, which will include all forest patches

\begin{tabular}{|c|c|c|c|c|}
\hline Forest Name & $\begin{array}{r}\text { Area in } \\
2001 \text { (ha) }\end{array}$ & $\begin{array}{r}\text { Area in } \\
1974 \text { (ha) }\end{array}$ & $\begin{array}{r}\text { Change } \\
\text { (ha) }\end{array}$ & $\begin{array}{r}\text { Change } \\
(\%)\end{array}$ \\
\hline Ben Rabeni & 20.51 & 15.23 & 5.27 & 35 \\
\hline Kwanocwane & 78.76 & 56.19 & 22.57 & 40 \\
\hline Kwanonkongodo & 121.64 & 119.52 & 2.11 & 2 \\
\hline Lubhelu & 119.92 & 103.43 & 16.49 & 16 \\
\hline Ludada & 55.96 & 38.72 & 17.24 & 45 \\
\hline Manyonyoba & 147.76 & 110.61 & 37.14 & 34 \\
\hline Migqibisa 1 & 35.26 & 20.17 & 15.08 & 75 \\
\hline Migqubisa 2 & 63.96 & 49.38 & 14.58 & 30 \\
\hline Mpindwana & 129.54 & 116.27 & 13.27 & 11 \\
\hline Ndimiti & 97.95 & 42.03 & 55.91 & 133 \\
\hline Ngroboji & 64.13 & 38.70 & 25.43 & 66 \\
\hline Ngwane & 219.24 & 146.00 & 73.24 & 50 \\
\hline Nkelekete & 305.77 & 132.27 & 173.50 & 131 \\
\hline Nqweleni & 173.28 & 107.81 & 65.47 & 61 \\
\hline
\end{tabular}

4. Reduced reliance on building materials from natural resources because of an increase in employment and the widespread access to social grants, enabling people to purchase building materials from hardware suppliers.

5. Less cultivation and many abandoned fields.

6. Change in cultivation practices, from large cultivated fields to smaller home gardens.

Nine of the 11 experts $(81 \%)$ noted that, apart from the forest edges expanding, the interiors of forests had also increased in density. They linked this to the reduced accessibility of forests by humans and livestock because of the six factors mentioned above.

All the experts believed that fire would have a positive effect on grazing by curtailing forest expansion, and by promoting the growth of green grass. They also believed that the absence of fire would cause forests and woodland areas to expand. All of them used fire from time to time for a variety of purposes, such as promoting livestock grazing, preventing forests from expanding, clearing land for cultivation, and controlling ticks. All the experts believed fire could be useful, and that it would only be dangerous if used irresponsibly. 
Fig. 2. Sizes of 14 forest patches at Nqabara in 1974 and 2001.

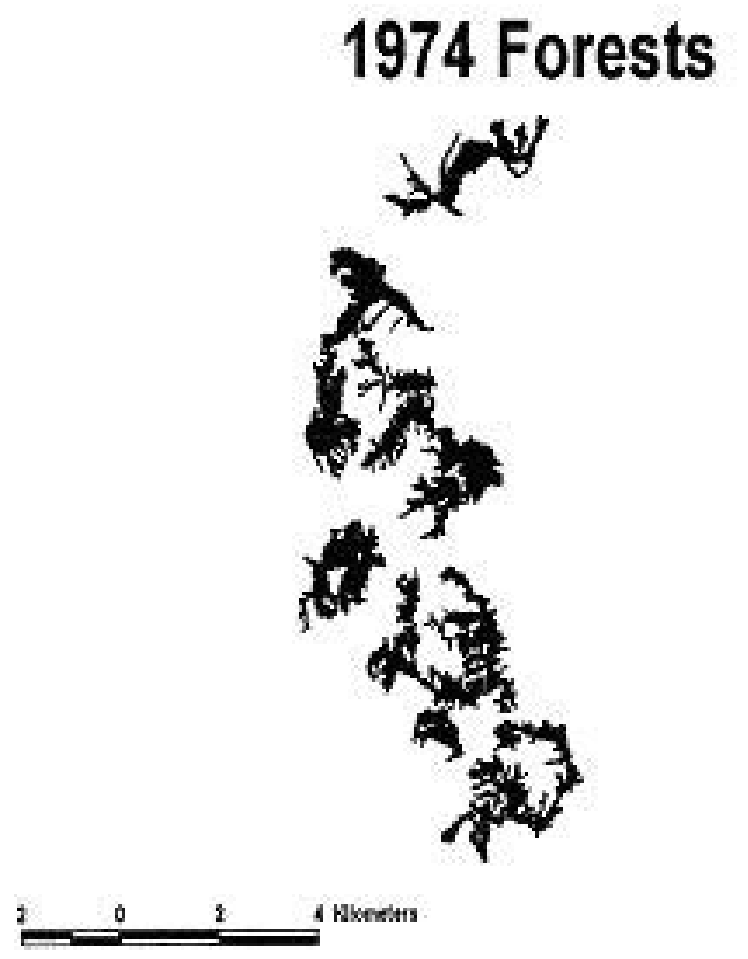

\section{Forests}

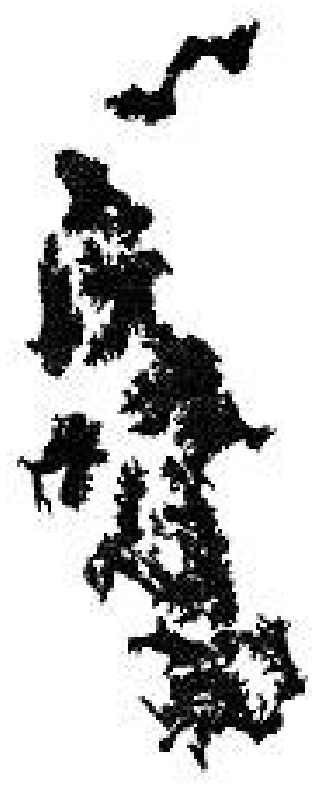

Panst Obrates

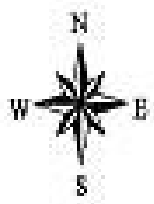

\section{General Local Knowledge about Land-cover Change}

The 40 randomly selected respondents also knew that forest and woodland land cover had increased since 1974. They identified three factors affecting changes in the sizes of forests: changes in cultivation, identified by $75 \%$ of respondents; changes in grazing, identified by $25 \%$; and changes in fire frequency, identified by only one respondent. Seventy-five percent of them agreed that fire affected the edge of the forest, but only 10 respondents $(25 \%)$ mentioned that fire affected forest interiors.

The randomly selected participants' understanding of the effects of fire on grassland was somewhat simplistic (Table 3). Although most of them $(67.5 \%)$ believed that fire affected numbers of woody plants growing in the grassland, $62.5 \%$ believed that the absence of fire would favor grass and lead to the expansion of grasslands, and $72.5 \%$ believed that fire would have a negative effect on grazing, in contrast to the scientific belief that frequent fires suppress woody plant growth (Bond et al. 2003a), remove old growth, and stimulate growth of green grass for grazing (O'Connor and BredenKamp 1997). Only one of the randomly selected respondents stated that fire promoted grazing. Almost $88 \%$ of the randomly selected respondents stated that fire was dangerous to both natural and human environments, and that they feared it. However, $67.5 \%$ of them sometimes burned on purpose, mainly on a small scale to open land for cultivation. 
Table 2. Local experts' views $(n=11)$ on causal factors of forest change

\section{Exotic tree species that people do not use:}

Forest is large now because there are trees that didn't grow here before.

Different types of trees now grow in the forest, which makes it denser.

Most of the trees that grow here were not here before and they destroy and out-compete the trees that are used by people.

New trees that are of no use to people are left and not cut down and so the forest became denser. These trees grew quickly and so the forest changed rapidly. These trees are out-competing the trees the community uses.

New trees that people do not use, and so do not cut, increase the size of the forest. These trees destroy the important trees.

\section{Forests grow because fire clears land, then forests take hold:}

After a fire more plants and trees grow back, which adds to the size and density of forest.

Fire can open up areas and small trees can grow in summer rain and then become part of the forest.

Fire does not enter the forest, so does not affect it, but burns the edge and new trees grow normally, e.g., Umnga.

Plants on the edge of the forest are destroyed by fire but this fire does not stop the forest from growing.

In winter, there is fire that burns the forest. In summer, the trees grow back and grow bigger and denser. But don't think that fire affects the shape or size of the forest.

\section{Forests grow because people abandon homesteads:}

The village was on the edge of the forest in 1974, now in 2005 the whole area is covered by forest.

Forest followed the stream in the past. There were homes near the stream and cows used to graze. The homes have gone and so have the cows.

Between 1971 and 1973, people moved to be on top of the hill and near the road, the area where they lived has now become part of the forest.

From 1987-1988 people moved to Fubesi to be near the road and services and when they left the forest started to grow.

People were moved because of apartheid and their land was overrun by forest.

\section{Forests grow because people stop cultivation:}

Fields that were cultivated in 1974 have now been overrun by the forest.

Places where people used to cultivate are now forests and people have moved to another village to cultivate.

It is natural that the trees take over abandoned land.

The people stopped cultivating the land and the forest took over.

This place was used for farming and cultivation, but these people stopped and forest took over the land. 


\section{Natural expansion:}

Change is natural; the forest became bigger and took over the grassland.

\section{People no longer cut so many trees for building materials:}

People nowadays use more blocks and bricks for building rather than trees.

\section{DISCUSSION}

\section{Landscape Change}

There has been a significant increase in the size of forests in the Nqabara AA. This goes against conventional perceptions of trends in forests in communal areas (von Maltitz and Shackleton 2004). The expansion of forests is not a new phenomenon and has been shown to occur in West Africa by Fairhead and Leach (1998), who found that people's land use and settlements had a major effect on the distribution and expansion of forests. Tree density increases with increasing $\mathrm{CO}_{2}$ levels, and corresponding fire suppression caused by reduced fuel loads could explain current trends in woody plant encroachment in many parts of Africa (Bond et al. 2003b).

The reason for the change of the forests varied among the respondents and no two respondents gave the same combination of factors that resulted in the change in size and density. The experts did, however, give combinations of factors as a cause of the change whereas the randomly selected household interviewees only gave one causal factor for change.

The local experts' knowledge was remarkably consistent with scientists' understanding of landscape change in forest grassland mosaic ecosystems such as the Wild Coast. They understood that fire normally originated in grasslands and affected forest margins (Scholes 1997, Trollope 1999, van Wilgen et al. 2003, van Wilgen 2005) and that frequent fires tend to suppress woody plant growth, particularly of saplings in grassland (Versfeld and van Wilgen 1986, Solbrig et al. 1992, Trollope 1999, Bond et al. 2003a, van Wilgen 2005). They also knew that frequent fires can lead to the transformation of forest and woodland to grassland (Scholes and Walker 1993, O'Connor and Bredenkamp 1997, Scholes 1997), and understood that fire removes moribund grass, leading to the renewal of grassland (Scholes and Walker 1993, van Wilgen et al. 2003, van Wilgen 2005). The experts also provided additional insights, which were not found in the literature but which made much logical sense: for example, that an increase in woodland cover eventually resulted in forest interiors becoming denser than before, and that changes in cultivation practices could affect land cover.

Perhaps the greatest LEK contribution was their understanding of the ultimate drivers (sensu MA 2003) of land-cover change. The local experts confirmed that national policies and macroeconomic factors changed rural resource use patterns. When household incomes change due to remittances, social grants, and job creation as a result of government policies, resource use changes from forest products to store-bought materials. This causes an increase in forest cover and density as natural resource harvesting is reduced. Local experts also told us that the unavailability of child labor, because of government policies ordering compulsory school attendance for children under 15 , meant that herd boys were no longer available to keep livestock out of unfenced fields. The most cost-effective alternative, rather than fencing the fields, was to start cultivating smaller home gardens that could be fenced or supervised (Andrew and Fox 2004). This contributed to an increase in forest cover because abandoned fields reverted to forests. The provision of piped water to villages (Statistics SA 2001), the result of macro policy factors, further contributed to the shift toward home gardens, and local experts alluded to this too.

The experts told us that the process of human movement, stopping cultivation, lack of fire, and 
Table 3. A comparison between the beliefs of local experts $(n=11)$ and local generalists $(n=40)$ about the causes of land-cover change at Nqabara

\begin{tabular}{|c|c|c|c|c|c|}
\hline & \multicolumn{2}{|c|}{ Local experts $(n=11)$} & \multicolumn{2}{|c|}{$\begin{array}{l}\text { Randomly selected } \\
\text { respondents }(n=40)\end{array}$} & \multirow[t]{2}{*}{ Significance } \\
\hline & Number & Proportion & Number & Proportion & \\
\hline $\begin{array}{l}\text { Forest sizes have increased } \\
\text { over the past } 30 \text { years }\end{array}$ & 11 & 1.00 & 40 & 1.00 & NS \\
\hline $\begin{array}{l}\text { Fire affects plant species on } \\
\text { forest margins }\end{array}$ & 11 & 1.00 & 30 & 0.75 & $*$ \\
\hline $\begin{array}{l}\text { Fire affects plant species in } \\
\text { grasslands }\end{array}$ & 11 & 1.00 & 33 & 0.83 & NS \\
\hline $\begin{array}{l}\text { Forest interiors have changed } \\
\text { over the past } 30 \text { years }\end{array}$ & 9 & 0.82 & 10 & 0.25 & $* *$ \\
\hline $\begin{array}{l}\text { Forest size is affected by } \\
\text { cultivation }\end{array}$ & 5 & 0.45 & 30 & 0.75 & * \\
\hline $\begin{array}{l}\text { Forest size is affected by } \\
\text { shifting homesteads }\end{array}$ & 5 & 0.45 & 0 & 0.00 & $* *$ \\
\hline Forest size is affected by fire & 6 & 0.55 & 1 & 0.03 & $* *$ \\
\hline $\begin{array}{l}\text { Forest size is affected by } \\
\text { useless, invasive plants }\end{array}$ & 7 & 0.64 & 0 & 0.00 & $* *$ \\
\hline $\begin{array}{l}\text { Forest size is naturally } \\
\text { expanding }\end{array}$ & 4 & 0.36 & 0 & 0.00 & $* *$ \\
\hline $\begin{array}{l}\text { Forest size is affected by } \\
\text { people's use of building } \\
\text { materials }\end{array}$ & 1 & 0.09 & 0 & 0.00 & $* *$ \\
\hline Fire reduces grazing & 0 & 0.00 & 29 & 0.73 & $* *$ \\
\hline Fire improves grazing & 11 & 1.00 & 1 & .03 & $* *$ \\
\hline $\begin{array}{l}\text { Absence of fire causes grass } \\
\text { to increase }\end{array}$ & 0 & 0.00 & 25 & 0.63 & $* *$ \\
\hline
\end{tabular}

NS not significant; $* \mathrm{P}<0.05 ; * * \mathrm{P}<0.01$

forest expansion could all be linked. Under the Betterment Programme in South Africa (Letsoalo and Rogerson 1982), people were grouped together in tribal communities that would make their governing easier. Therefore, people were forced to relocate from scattered settlements into centralized villages. This meant abandoning fields and their homesteads, which were recolonized by forests. In more recent times, people have again moved, this time to be to nearer to infrastructure such as roads, clinics, telephone lines, and water pipelines. When people moved homesteads, they abandoned cultivation and their fields and homesteads reverted to forest (Andrew and Fox 2004). This also 
influenced fire regimes, as people frequently used fire to open up land for cultivation.

There were, however, major inconsistencies between the randomly selected respondents' understanding and that of local experts and scientists. The reasons for these inconsistencies are linked to the limitations of LEK and temporal perception (Berkes and Jolly 2001), local "experts" vs. "generalists" (Kaschula et al. 2005), and spatial perception (Fabricius et al. 2006). The 40 randomly selected respondents had a shallower knowledge of fire as an ecosystem process than the local experts had. When the randomly selected participants were questioned about landscape change, a relatively slow process, the predominant response was that fire suppression would mean "lots of grass would grow." The actual change that would take place, however, is more likely to be a gradual increase in woody biomass that would increase the forest size (O'Connor Bredenkamp 1997, Scholes and Walker 1993, Scholes 1997). Only the 11 experts understood this slow process.

Our findings corroborate the notion that knowledge is unevenly spread through a community and that, at least in modern rural societies, "local knowledge" is held by individuals and not groups. In order to gather useful local knowledge, therefore, it is imperative to identify and talk to the local experts (Berkes 1999), i.e., individuals within a community who specialize in the use of a particular resource, such as traditional healers who collect medicinal plants from the forest. Local experts should be identified through discussions with the traditional authorities or local institutions, as they will know who the specialist users are within the community (Verlinden and Dayot 2005).

The general inhabitants of Nqabara AA appear to have a better understanding of easily visible processes (Moller et al. 2004) than of "hidden" processes that are difficult to detect through casual observation. This is demonstrated by their good understanding of the increase in land cover, which can easily be benchmarked against fixed objects such as roads or homesteads.

\section{CONCLUSION}

Local experts and scientists had complementary knowledge regarding land-cover change at Nqabara, but all three types of knowledge also had flaws. Scientists are able to quantify land-cover change and can relate the ecological role of fire on the Wild Coast to that in other areas. They can also develop and test sophisticated models of the impact of, for example, fire intensity on vegetation composition (van Wilgen et al. 2003). Scientists are able to monitor variables that are difficult to detect through mere observation and relate them to landscape processes, e.g., atmospheric carbon to fire regimes (Bond et al. 2003a, b). However, scientists are inept at modeling and understanding complex social-ecological systems and multi-scale feedbacks, and lack the data (and sometimes the insights) to assess these complex interactions empirically. Local experts are able to intuitively assess and describe such complex and multi-scale processes, albeit qualitatively, and can provide a historical perspective based on intergenerational transfer of information.

Nadasny (1999), Gadgil et al. (2003), and Kaschula et al. (2005) ask the question: can LEK and science be integrated? Where there have been efforts to integrate the two, there has been a tendency to use Western science norms to judge LEK (Heyd 1995), even though it has its own rules of rationality and origins that differ from those of formal science.

Science and LEK have great potential to complement one another to enhance our understanding of ecosystem processes, especially in understudied regions such as Nqabara AA. This study has shown that science and LEK can converge. It is important to bear in mind, however, that they are not identical and are developed in different ways. We are acutely aware that our study merely "scratched the surface" of local knowledge about land-cover change and the role of fire, and that we adopted a very "rational" and positivist approach. Certain components of local knowledge and customs (particularly about fire) are sacred and do not fall in the "rational" domain. Scientists should, therefore, be cautious and sensitive to differences in world views when attempting to bridge the gap between local knowledge and science.

Responses to this article can be read online at:

http://www.ecologyandsociety.org/vol12/iss 1/art10/responses/ 


\section{Acknowledgments:}

We thank the communities of the Nqabara Administrative Area for requesting and participating in this research. We are grateful to James Gambiza and Georgina Cundill of Rhodes University, Brian van Wilgen of CSIR, and Richard Cowling of Nelson Mandela Metropolitan University for their valuable input. Dan Brockington gave us crisp advice about local garden produce, and two anonymous referees made extremely constructive comments.

\section{LITERATURE CITED}

Agrawal, A., and C. C. Gibson. 1999. Enchantment and disenchantment: the role of community in natural resource conservation. World Development 27:629-649.

Alexander M., K. Chamundeeswari, A. Kambu, M. Ruiz, and B. Tobin. 2004. The role of registers and databases in the protection of traditional knowledge - a comparative analysis. United Nations University, Institute for Advanced Studies, Tokyo, Japan.

Andrew, M., and R. Fox. 2004. "Undercultivation" and intensification in the Transkei: a case study of historical changes in the use of arable land in Nompa, Shixini. Development Southern Africa 21:687-706.

Bebbington, A., and T. Perreault. 1999. Social capital, development, and access to resources in highland Ecuador. Economic Geography 75:395418.

Berkes, F. 1999. Sacred ecology: traditional ecological knowledge and resource management. Taylor and Francis, Philadelphia, Pennsylvania, USA; London, UK.

Berkes, F., and C. Folke. 2002. Back to the future: ecosystem dynamics and local knowledge. Pages 121-144 in L. Gunderson and C. S. Holling, editors. Panarchy: understanding transformations in human and natural systems. Island Press, Washington, D. C., USA.
Berkes, F., and D. Jolly. 2001. Adapting climate change: social-ecological resilience in a Canadian western artic community. Conservation Ecology 5:1-18.

Berkes, F., J. Colding, and C. Folke, editors. 2003. Navigating social-ecological systems: building resilience for complexity and change. Cambridge University Press, Cambridge, UK.

Bond, W. J., G. F. Midgley, and F. I. Woodward. 2003a. What controls South African vegetationclimate or fire? South African Journal of Botany 69:79-91.

Bond, W. J., G. F. Midgley, and F. I. Woodward. 2003b. The importance of low atmospheric $\mathrm{CO}_{2}$ and fire in promoting the spread of grasslands and savannas. Global Change Biology 9:973.

Carter, G. M. 1959. A political scientist in Africa. African Studies Bulletin 2(4):1-12.

Cundill G., C. Fabricius, and N. Marti. 2005. Foghorns to the future: using knowledge and transdisciplinarity to navigate complex systems. Ecology and Society 10:8. [online] URL: http://ww w.ecologyandsociety.org/vol10/iss2/art8.

Donovan, D. G., and R. K. Puri. 2004. Learning from traditional knowledge of non-timber forest products: Penan Benalui and the autecology of Aquilaria in Indonesian Borneo. Ecology and Society 9(3): 3. [online] URL: http://www.ecologya ndsociety.org/vol9/iss3/art3.

ESRI. 2001. ArcView GIS: the geographical information system for everyone. ESRI Publications, Redlands, California, USA.

Fabricius C., R. J. Scholes, and G. Cundill. 2006. Mobilising knowledge for ecosystem management. Chapter 9 in W. V. Reid, F. Berkes, T. J. Wilbanks, and D. Capistrano, editors. Bridging Scales and Knowledge Systems. Concepts and Applications in Ecosystem Assessment. Island Press, Washington, D.C., USA.

Fairhead, J., and M. Leach. 1998. Reframing deforestation. Global analysis and local realities: studies in West Africa. Routledge, London, UK.

Fay, D. 2003. The increasing and decreasing importance of kinship for access to land in the 
Eastern Cape: path-dependent social change and its implications for land tenure reform. Fort Hare Institute of Social and Economic Research, Alice, South Africa.

Gadgil, M., P. Olsson, F. Berkes, and C. Folke. 2003. Exploring the role of local ecological knowledge in ecosystem management: three case studies. Pages 189-209 in F. Berkes, J. Colding, and C. Folke, editors. Navigating social-ecological systems: building resilience for complexity and change. Cambridge University Press, Cambridge, UK.

Hardison, P. D. 2005. The report on traditional knowledge registers (TKRs) and related traditional knowledge databases (TKDBs). UNEP/CBD/ $\mathrm{WG} 8 \mathrm{~J} / 4 / \mathrm{INF} / 9$, 1. Prepared for the Secretariat of the Convention on Biological Diversity, Montreal, Quebec, Canada.

Heyd, T. 1995. Indigenous knowledge, emancipation and alienation. Knowledge and Policy 8:63-74.

Huntingdon, H. P. 2000. Using traditional ecological knowledge in science: methods and applications. Ecological Applications 10:12701274.

Kaschula, S. A., W. E. Twine, and M. C. Scholes. 2005. Coppice harvesting of fuel wood species on a South African common: utilizing scientific and indigenous knowledge in community based natural resource management. Human Ecology 33:387418.

Keirungi, J., and C. Fabricius. 2005. Selecting medicinal plants for cultivation at Nqabara on the Eastern Cape Wild Coast, South Africa. South African Journal of Science 101: 497-501.

Kepe, T., and I. Scoones. 1999. Creating grasslands: social institutions and environmental change in Mkambati Area, South Africa. Human Ecology 27:29-44.

Korte, G. 2001. The GIS book. $5^{\text {th }}$ edition. OnWord Press, Australia.

Le Roux, R., and A. Nahman. 2005. An economic valuation of the biodiversity of the Wild Coast and assessment of potential financing mechanisms for its conservation. Unpublished report, no. ENV-S-C 2005-016, CSIR, Stellenbosch, South Africa.
Leach M., and J. Fairhead. 2000. Fashioned forest pasts, occluded histories? International environmental analysis in West African locales. Development and Change 31:35-59.

Letsoalo, E. M., and C. M. Rogerson. 1982. Rural "development" planning under apartheid: betterment planning in Lebowa, South Africa. Geoforum 13:301-314.

Lobe, K., and F. Berkes. 2004. The padu system of community-based fisheries management: change and local institutional innovation in south India. Marine Policy 28:271-281.

Mafa Environment and Development cc. 2003. Feasibility assessment of PFM projects in the Nqabara Administrative Area. Final Report to GTZ Transform, Danida and DWAF, Pretoria, South Africa.

Mafa Environment and Development cc. 2005. Nqabara community management plan. Unpublished Report, GTZ Transform, Pretoria,South Africa.

Martin, G. J. 2004. Ethnobotany: a methods manual. Earthscan, London, UK.

Mauro F., and P. D. Hardison. 2000. Traditional knowledge of indigenous and local communities: international debate and policy initiatives. Ecological Applications 10:1263-1269.

Millennium Assessment. 2003. Ecosystems and human well-being: a framework for assessment. Island Press, Washington, DC, USA.

Moller, H. F., F. Berkes, L. O'Brian, and M. Kislalioglu. 2004. Combining science and traditional ecological knowledge: monitoring populations for co-management. Ecology and Society 9(3): 2. (online) URL: http://www.ecologya ndsociety.org/vo19/iss3/art2/.

Nadasny, P. 1999. The politics of TEK: power and the "integration" of knowledge. Arctic Anthropology 36: $1-18$.

O'Connor, T. G., and G. J. Bredenkamp. 1997. Grasslands. Pages 215-245 in R. M. Cowling, D. M. Richardson, and S. M. Pierce, editors. Vegetation of southern Africa. Cambridge University Press, Cambridge, UK. 
Oudwater, N., and A. Martin. 2003. Methods and issues in exploring local knowledge of soils. Geoderma 111:387-401.

Palmer, R., H. Timmermans, and D. Fay. 2000. From conflict to negotiation - nature-based development on South Africa's Wild Coast. Human Science Research Council, Grahamstown, South Africa.

Reyers, B., and E. Ginsburg. 2005. Wild Coast conservation and sustainable development project: conservation assessment of the Wild Coast. Unpublished report, no. ENV-S-C 2005-022, CSIR, Stellenbosch, South Africa.

Rosner, B. 2000. Fundamentals of Biostatistics. $5^{\text {th }}$ Edition. Thomson Learning, Stamford, Connecticut, USA.

Satellite Image Corporation. 2006. Orthorectification. (online) URL: http://www.satimagingcorp.com/svc/ orthorectification.html. Accessed 22/10/2006.

Scholes, R. J. 1997. Savanna. Pages 258-277 in R. M. Cowling, D. M. Richardson, and S. M. Pierce, editors. Vegetation of southern Africa. Cambridge University Press, Cambridge, UK.

Scholes R. J., and R. Biggs. 2004. Ecosystem services in Southern Africa: the regional-scale component of the South African millennium ecosystem assessment. CSIR, Pretoria, South Africa.

Scholes, R. J., and B. H. Walker. 1993. An Africa savanna: synthesis of the Nylsvley study. Cambridge University Press, Cambridge, UK.

Solbrig, O. T., G. Goldstein, E. Medina, G. Sarmiento, and J. Silva. 1992. Responses of tropical savannas to stress and disturbance: a research approach. Pages 63-74 in M. K. Wali, editor. Ecosystem rehabilitation: volume 2: ecosystem analysis and synthesis. SPB Academic Publishing, the Hague, the Netherlands.

South Africa Department of Land Affairs. 2004. Surveys and Mapping. [online] URL:http://w3sli.w cape.gov.za. Accessed 12 April 2005

Statistics SA. 2001. 2001 Census data for Mbhashe, Ward 17. [online] URL: http://www.statssa.gov.za/ census2001/atlasward2/index.html. Accessed 12 April 2005.

Trollope, W. 1999. Veld burning. Pages 217-245 in N, Tainton, editor. Veld management in South Africa. University of Natal Press, Natal, South Africa.

Trosper, R. 2002. Northwest coast indigenous institutions that supported resilience and sustainability. Ecological Economics 41:329-344.

van Wilgen, B. 2005. Managing fires: the science behind the smoke. Quest 1:26-33.

van Wilgen, B., W. Trollope, H. Biggs, A. Potgieter, and B. Brockett. 2003. Fire as a driver of ecosystem variability. Pages $149-170$ in J. T. du Toit, K. H. Rogers, and H. C. Biggs, editors. The Kruger experience: ecology and management of savanna heterogeneity. Island Press, Washington, D.C., USA.

Verlinden, A., and B. Dayot. 2005. A comparison between indigenous environmental knowledge and a conventional vegetation analysis in north central Namibia. Journal of Arid Environments 62:143175.

Versfeld, D., and B. van Wilgen. 1986. Impact of woody aliens on ecosystem properties. Pages 239246 in I. A. W. Macdonald, F. J. Kruger, and A. A. Ferrar, editors. The ecology and management of biological invasions in southern Africa. Oxford University Press, Oxford, UK.

von Maltitz, G. P., and S. E. Shackleton. 2004. Use and management of forests and woodlands in South Africa: stakeholders, institutions and processes from past to present. Pages 109-135 in M. J. Lawes, H. A. C. Eeley, C. M. Shackleton, and B. G. S. Geach, editors. Indigenous forests and woodlands in South Africa: policy, people and practice. University of KwaZulu-Natal Press, KwaZulu-Natal, South Africa.

Wang, S. 2004. One hundred faces of sustainable forest management. Forest Policy and Economics 6:205-213. 